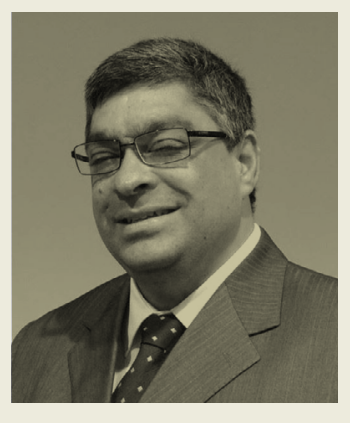

\title{
O PROBLEMA É A LARANJA
}

Como bom paulistano que sou, outro dia fui tomar café da manhã numa padaria perto de casa e vi que lá havia uma nova máquina de espremer laranjas: high tech, bonita, sofisticada. Então, brinquei com o rapaz do balcão que sempre me atende: "Meu caro, com essa máquina não tem como não fazer um bom suco de laranja, hein?". Mais do que depressa ele me respondeu: "Pois é, a máquina é boa mesmo, mas se a laranja não for, não tem jeito, o suco fica ruim". Fiquei sem reação. E sem resposta, claro.

No mesmo instante me veio à cabeça o momento político e econômico que estamos vivendo no Brasil. Seja pessoalmente ou nas mídias sociais, quase todos os dias discutimos a urgente necessidade de o país realizar reformas: reforma tributária, reforma política, reforma previdenciária, reforma eleitoral, reforma, reforma, reforma. Esta se tornou a palavra de ordem na fala da maioria dos brasileiros. Mas surge uma reflexão importante: será que apenas reformas, em quaisquer instâncias, vão resolver o problema do Brasil? Aonde nos levará promover reformas de ordem tributária e eleitoral, por exemplo, e continuar com os atuais políticos? É possível esperar alguma mudança minimamente eficaz, que se torne perene e nos impulsione a novos horizontes como nação? A história recente parece mostrar que não.

Tenho a crença de que só vamos nos tornar de fato uma grande nação quando os cargos legislativos e executivos do Estado (esferas municipal, estadual e federal) forem ocupados por pessoas honestas, com experiência em gestão, bem preparadas academicamente, que aceitem o desafio de construir uma nação e pensem em ações e projetos de curto e longo prazo.

Claro, o Brasil precisa realizar várias reformas para crescer e retomar o caminho da prosperidade. Algumas, inclusive, estão engavetadas há anos, esperando a boa vontade dos governos e das casas legislativas. Desse modo, ainda que as reformas sejam necessárias e urgentes, não podemos desconsiderar o fato de que o país precisa de novos governantes, que pensem menos em si e em seus partidos - com suas respectivas ideologias - e que sejam capazes de promover a mudança que tanto necessitamos.

Meu amigo da padaria conseguiu traduzir de forma bem simples um conceito importante: não adianta termos uma máquina potente e eficaz (considerando aqui as estruturas, os mecanismos, as leis etc.) se a qualidade da laranja não for boa (referindo-se, claro, à grande parte dos atuais líderes e governantes). São as laranjas novas e boas (cidadãos bem preparados, experientes, honestos e engajados) que produzirão o bom suco (ações de mudança). Assim, para mim, o problema é a laranja.

Uma pergunta que tem me inquietado ultimamente é: será que eu e você não somos essas laranjas novas e boas? Estou convencido de que chegou o tempo de falarmos menos e fazermos mais, de maneira pragmática e efetiva, abraçando o desafio de reerguer este país. 